\title{
An antigen-capture enzyme-linked immunosorbent assay (ELISA) to detect isometamidium chloride in Oncorhynchus spp.
}

\author{
B. F. Ardelli, P. T. K. Woo* \\ Department of Zoology, University of Guelph, Guelph, Ontario N1G 2W1, Canada
}

\begin{abstract}
An antigen-capture enzyme-linked immunosorbent assay (ELISA) was developed to detect and measure isometamidium chloride in the plasma of Oncorhynchus tshawytscha and $O$. mykiss. Isometamidium-ovalbumin conjugate and anti-isometamidium antibodies were used to coat polystyrene plates. The peroxidase saturation technique was used to optimize the coating antigen concentration; it demonstrated low affinity of the isometamidium-ovalbumin conjugate but high affinity of the anti-isometamidium antibodies for polystyrene surface sites. The optimal conditions of antiisometamidium antibodies to coat plates was at pH 7.3 and a $1: 1000$ dilution $\left(0.0012 \mathrm{mg} \mathrm{m}^{-1}\right.$ protein). The ELISA was sensitive as it detected $0.0006 \mathrm{mg} \mathrm{m}^{-1}$ of isometamidium in fish plasma. Isometamidium diluted with saline could not be detected at concentrations less than $0.05 \mathrm{mg} \mathrm{mi}^{-1}$. The results indicate that this ELISA is much more sensitive when isometamidium is bound to plasma than unbound isometamidium in saline.
\end{abstract}

KEY WORDS: Antigen-capture ELISA. Isometamidium - Oncorhynchus

\section{INTRODUCTION}

Cryptobia salmositica causes morbidity and mortality in the economically important Oncorhynchus spp. (Woo \& Poynton 1995). Ardelli \& Woo (unpubl.) showed that an intramuscular injection of $1.0 \mathrm{mg} \mathrm{kg}^{-1}$ of isometamidium was effective against $C$. salmositica in juvenile and adult chinook salmon $O$. tshawytscha and rainbow trout $O$. mykiss. There was a significant drop in parasitaemia $2 \mathrm{wk}$ after drug treatment; all treated juvenile chinook salmon survived while 100\% of untreated fish died from cryptobiosis.

A competitive enzyme-linked immunosorbent assay (ELISA) was described to measure isometamidium in the sera of cattle treated for trypanosomiasis (Whitelaw et al. 1991). This assay required only $5 \mu$ lof test serum and was sensitive to a level of $0.5 \mathrm{pg} \mathrm{m}^{-1}$. A modification of this assay was developed (Eisler et al. 1993) which utilized a liquid-phase isometamidium competing with a solid-phase bound isometamidium-protein conjugate for biotinylated sheep anti-isometamidium IgG.

\footnotetext{
•Corresponding author. E-mail: pwoo@uoguelph.ca
}

These assays were developed for use in mammalian systems and our preliminary data indicate that they did not produce consistent results with our piscine system. This study describes an antigen capture ELISA for use with piscine systems.

\section{MATERIALS AND METHODS}

Preparation of antigen. Isometamidium chloride (Rhône Merieux, Lyon, France) was conjugated to porcine thyroglobulin using a diazotization reaction. Briefly, $0.5 \mathrm{mg} \mathrm{ml}^{-1}$ of isometamidium was dissolved in $1.0 \mathrm{ml}$ of concentrated $\mathrm{HCl}$ (diluted with $2.0 \mathrm{ml}$ of distilled water) and $1.0 \mathrm{ml}$ of a $8 \mathrm{mg} \mathrm{ml}^{-1}$ solution of sodium nitrite was added to the isometamidium- $\mathrm{HCl}$ mixture and placed at $4^{\circ} \mathrm{C}$ for $10 \mathrm{~min}$. After $10 \mathrm{~min}$, the isometamidium- $\mathrm{HCl}$ solution was added to porcine thyroglobulin (Sigma, St. Louis, Missouri, USA) dissolved in $200 \mathrm{mM}$ of phosphate buffer $(\mathrm{pH} 7.0)$ and incubated for $2 \mathrm{~h}$ at $4^{\circ} \mathrm{C}$; the final ratio was $0.25(\mathrm{w} / \mathrm{w})$ of isometamidium:porcine thyroglobulin. The conjugate was dialysed for $24 \mathrm{~h}$ against $5 \%$ acetic acid, and used as an antigen to prepare anti-isometamidium 
antibodies. The same procedure was used to prepare an isometamidium-ovalbumin conjugate with a ratio of $0.025(w / w)$ of ovalbumin. This conjugate was used to coat the surface of polystyrene plates in the antigencapture ELISA test (see below).

Integrity of isometamidium-porcine thyroglobulin (or ovalbumin) conjugate (see Philips et al. 1967). A $100 \mu \mathrm{l} \mathrm{sample} \mathrm{of} \mathrm{a} 1 \mathrm{mg} \mathrm{ml}^{-1}$ solution of isometamidium ( $n=10$ ) or isometamidium-porcine thyroglobulin conjugate $(\mathrm{n}=10)$, diluted to a final volume of $4.0 \mathrm{ml}$, was added to glass-stoppered bottles each containing $2.0 \mathrm{~g}$ of $\mathrm{NaCl}$. Controls $(n=10)$ consisted of $100 \mu \mathrm{l}$ of saline diluted to $4.0 \mathrm{ml}$. Ether $(25.0 \mathrm{ml})$ and $30 \% \mathrm{NaOH}$ $(1.0 \mathrm{ml})$ were quickly added to the stoppered bottles. The bottles were shaken mechanically for $10 \mathrm{~min}$ and ether extract $(20.0 \mathrm{ml})$ was removed and added to glass-stoppered bottles containing $4.0 \mathrm{ml}$ of $0.1 \mathrm{M}$ acetate buffer ( $\mathrm{pH} 4.7$ ). The bottles were shaken for $10 \mathrm{~min}$ and the absorbance of the buffer layer was read at $380 \mathrm{~nm}$ using a spectrophotometer. An analysis of variance (ANOVA) $(p \geq 0.05)$ was used to determine significant differences in the absorption of isometamidium, isometamidium-porcine thyroglobulin conjugate and controls.

Production of anti-isometamidium antibodies. Antiisometamidium antibodies were prepared using the following injection schedule. Pre-immune blood samples $\left(0.5 \mathrm{ml} \mathrm{fish}^{-1}\right)$ were taken from 10 adult rainbow trout Oncorhynchus mykiss (527.34 $\pm 35.62 \mathrm{~g})$. An emulsion of the conjugate and Freund's complete adjuvant $(1: 1)$ were injected at 2 sites intramuscularly (i.m.) such that the final concentration of conjugate was $2.5 \mathrm{mg}$. At $4 \mathrm{~d}$ after the first injection, the conjugate and Freund's incomplete adjuvant were injected at 2 sites i.m. such that the final concentration of adjuvant was $1.5 \mathrm{mg}$. The procedure was repeated on Day 7 (650 $\mu \mathrm{g}$ conjugate in Freund's incomplete adjuvant at 1 site i.m.) and Day 11 (650 $\mu \mathrm{g}$ conjugate in Freund's incomplete adjuvant at 1 site i.m.). At $28 \mathrm{~d}$ after the start of the immunization procedure $0.5 \mathrm{ml}$ of blood was withdrawn from the caudal vein of each fish and was used as the primary immune plasma. A week later fish were injected $\mathrm{i} . \mathrm{m}$. with $650 \mu \mathrm{g}$ of conjugate in Freund's incomplete adjuvant. Three days later $0.5 \mathrm{ml}$ of blood was withdrawn as the second immune plasma. At $42 \mathrm{~d}$, fish were injected with $650 \mu \mathrm{g}$ of conjugate only (adjusted to the appropriate concentration with saline), exsanguinated 7 d later, and all the blood was collected.

Purification of anti-isometamidium antibody (Smith 1992). Antibodies from immune plasma were purified using Anion Exchange Chromatography on Diethylamino-ethyl (DEAE) Cellulose with a Bio-Rad Serum IgG Purification Kit and Econo-Pac Serum IgG Purification Column (Bio-Rad Laboratories Ltd, Mississauga,
Ontario, Canada). Briefly, $5.0 \mathrm{ml}$ of gel slurry was suspended in $25.0 \mathrm{ml}$ of phosphate buffered saline (PBS = $-0.1 \mathrm{M}, 0.85 \% \mathrm{NaCl}_{1} \mathrm{pH}$ 7.2). The gel slurry was poured into the column and equilibrated with $25.0 \mathrm{ml}$ of PBS ( $\mathrm{pH}$ 7.2) by opening the stop-cock and allowing the buffer to drip out at a dropwise rate until it was approximately $0.5 \mathrm{~cm}$ from the top of the gel. The column was washed twice with $5.0 \mathrm{ml}$ of PBS and the eluted solution was discarded. A volume of antiisometamidium plasma $(3.0 \mathrm{ml})$ was added to the column and allowed to drip until it was approximately $0.5 \mathrm{~cm}$ from the top of the gel. PBS $(10.0 \mathrm{ml})$ was added to the column and the eluted solution was collected. The procedure was repeated until all the plasma had passed through the column. The protein concentration of the eluted volume was determined using the method of Bradford (1976). The IgG fraction was equilibrated in PBS by dialysis at $4^{\circ} \mathrm{C}$ for $24 \mathrm{~h}$ with a change of PBS every $2 \mathrm{~h}$. Anti-porcine thyroglobulin activity was removed from the antibody preparation by preadsorption with porcine thyroglobulin $\left(650 \mu \mathrm{g} \mathrm{ml}^{-1}\right.$ in PBS and Tween 20). The volume of PBS in the IgG fraction was reduced on a bed of polyethyleneglycol (PEG) until approximately $1.0 \mathrm{ml}$ and the IgG concentrated using Centricon ${ }^{\text {(2) }}$ centrifugal concentrators equipped with an anisotropic membrane. The protein in the sample was determined (Bradford 1976).

Immunoelectrophoresis to identify the purified immunoglobulin. A buffer system (for electrode vessel and gel) of $0.02 \mathrm{M}$ barbituric acid, $0.07 \mathrm{M}$ tris base $(\mathrm{pH} 8.6)$ and $0.03 \mathrm{M}$ calcium lactate was used. The gel $(1 \% \mathrm{w} / \mathrm{v})$ was boiled in buffer until all the agarose was dissolved and $9.0 \mathrm{ml}$ was poured onto the hydrophilic side of a $5 \times 10 \mathrm{~cm}$ gel bond film. After it had solidified, antigen wells and antibody troughs were punched and the agarose was removed from the sample wells but not from antibody troughs. The wells were filled with the purified antibody and a tracking dye (Bromophenol Blue). The gel was electrophoresed at $100 \mathrm{~V}\left(10 \mathrm{~V} \mathrm{~cm}^{-1}\right)$ until the dye was $30 \mathrm{~mm}$ from the sample well. The agar was removed from the antibody troughs and filled with plasma from the preimmune bleeding and isometamidium-spiked rainbow trout plasma. The gel was placed in a humid chamber for $24 \mathrm{~h}$ at $37^{\circ} \mathrm{C}$ for the precipitating arcs to develop and was then washed, pressed and stained according to Oudin (1980).

Optimization of solid-phase antigen concentration (Muñoz et al. 1986). The wells of a 96 -well microtitre plate were coated with either $0.1 \mathrm{mg} \mathrm{ml}^{-1}$ of anti-isometamidium antibodies or an isometamidium-ovalbumin conjugate at dilutions of $1: 10,1: 100,1: 1000,1: 3000$ and $1: 5000$ and $\mathrm{pH} 7.0,7.3,8.0,8.5,9.0$ and 9.6. Controls were at $1: 10,1: 100,1: 1000,1: 3000,1: 5000$ and no 
dilution of a $0.1 \mathrm{mg} \mathrm{ml}^{-1}$ solution of horseradish peroxidase (HRP) dissolved in PBS. After discarding the antigens the plates were washed once with PBS and $100 \mu \mathrm{lwell^{-1 }}$ of a $0.1 \mathrm{mg} \mathrm{m} \mathrm{m}^{-1}$ solution of HRP was dispensed into the wells. After $3 \mathrm{~h}$ at $37^{\circ} \mathrm{C}$ supernatants were discarded and the plates were washed 3 times with Tween-PBS and once with PBS. The substrate (100 $\mu$ l of p-nitrophenylphosphate) was added to each well in the plates. After $20 \mathrm{~min}$ in a shaker the reaction was stopped with $2.0 \mathrm{M}$ sulphuric acid $\left(50 \mu \mathrm{l}\right.$ well $\left.{ }^{-1}\right)$ and the optical density was read at $600 \mathrm{~nm}$. The antigen with the lowest optical density values indicated optimal binding to polystyrene plates and was used in the ELISA.

Antigen-capture enzyme-linked immunosorbent assay. The wells of a 96-well microtitre plate were coated with $50 \mu \mathrm{l}$ of a 1:1000 dilution of anti-isometamidium antibodies in carbonate-bicarbonate coating buffer, $\mathrm{pH} 7.3$. Plates were placed at $37^{\circ} \mathrm{C}$ for $2 \mathrm{~h}$ and washed twice in Tris-buffered saline (TBS) and Tween-Tris buffered saline (TTBS). Vacant sites in the wells were blocked with $200 \mu \mathrm{l}$ of $5 \%$ skim milk in TBS for $1 \mathrm{~h}$ at $37^{\circ} \mathrm{C}$ and washed as above. Test samples ( $50 \mu \mathrm{l}$; fish plasma or saline spiked with 2 -fold dilutions of a stock solution of $5.0 \mathrm{mg} \mathrm{ml} \mathrm{m}^{-1}$ of isometamidium) were added to wells and placed at $37^{\circ} \mathrm{C}$ for $2 \mathrm{~h}$. Negative controls were 2 -fold dilutions of fish plasma in PBS, wells containing no antigen, wells containing no anti-isometamidium antibody and wells containing no goat anti-trout immunoglobulin. Plates were washed and $50 \mu \mathrm{l}$ of a 1:1000 dilution of anti-isometamidium antibodies (in $3 \%$ skim milk in TBS) was again added to each well, incubated at $37^{\circ} \mathrm{C}$ for $2 \mathrm{~h}$ and washed. A 1:1000 dilution of affinity purified peroxidase labelled goat anti-trout immunoglobulin (Kirkegaard and Perry Laboratories, Burlington, Ontario, Canada) was added to each well and incubated at $37^{\circ} \mathrm{C}$ for $1 \mathrm{~h}$. Plates were washed and the substrate $(50 \mu \mathrm{l}$ of 2,2'-azino-di-[3-ethyl-benzthiazoline sulfonate (6)]) was added. Plates were shaken for $1 \mathrm{~min}$ and absorbance read at $405 \mathrm{~nm}$ using a Molecular Devices $V_{\text {max }}$ kinetic microplate reader.

Two-fold serial dilutions of naive fish plasma were made until a decrease in absorbance was not detected. The optical density value $(0.048 \pm 0.004)$ was subtracted from the optical density value of the undiluted plasma to obtain a baseline value for nonspecific binding to antigen. This value was then subtracted from the optical density values of plasma with known amounts of isometamidium. The adjusted values were used to plot a stan- dard curve with concentrations of isometamidium plotted against the absorbance of the samples. Optical density values of samples with less than 3 standard deviations of the mean of naive plasma were considered negative

\section{RESULTS}

The integrity of the isometamidium conjugates was assessed by comparing the absorbance of the conjugates to that of isometamidium. A significant difference ( $p=0.8245$ ) was not detected in the mean absorbance of isometamidium $(0.763 \pm 0.005)$ and the isometamidium-porcine thyroglobulin $(0.7635 \pm 0.006)$ or ovalbumin conjugate $(0.7637 \pm 0.004)$. Significant differences $(p=0.0001$ ) were detected between the absorbance of isometamidium or the conjugates and absorbance of controls $(0.0144 \pm 0.004)$.

The purified trout immunoglobulin reacted with isometamidium in trout plasma. Four precipitin lines were formed with isometamidium-spiked rainbow trout plasma but not with plasma from the pre-immune blood sample.

Polystyrene plates were coated with different concentrations of anti-isometamidium antibodies or an isometamidium-ovalbumin conjugate at neutral to highly alkaline $\mathrm{pH}$ and the non-coated surface sites were detected by peroxidase saturation. For both isometamidium-ovalbumin conjugate (Table 1) and anti-isometamidium antibodies (Table 2), peroxidase absorption (non-occupied active sites) decreased with an increase in antigen concentration. The conjugate had greater binding affinity than HRP for polystyrene at neutral $\mathrm{pH}$ and at $37^{\circ} \mathrm{C}$. Less binding of the conjugate was achieved at $\mathrm{pH} 9.6$ at $4^{\circ} \mathrm{C}$ compared to the conjugate at the same $\mathrm{pH}$, but at $37^{\circ} \mathrm{C}$ (Table 1). In addition,

Table 1. Optical density values (at $405 \mathrm{~nm}$ ) using a horseradish peroxidase (HRP) saturation technique to determine the coating of isometamidium-ovalbumin conjugate to polystyrene microtitre plates

\begin{tabular}{|c|c|c|c|}
\hline \multirow[t]{2}{*}{ Antigen } & \multirow[t]{2}{*}{ Dilution } & \multicolumn{2}{|c|}{$\begin{array}{l}\text { pH of carbonate-bicarbonate } \\
\text { coating buffer }\end{array}$} \\
\hline & & 7.0 & 9.6 \\
\hline \multirow[t]{2}{*}{ Conjugate at $37^{\circ} \mathrm{C}$ for $2 \mathrm{~h}$} & Undiluted & $3.628 \pm 0.080^{b}$ & $3.840 \pm 0.094$ \\
\hline & $1: 5000$ & $3.763 \pm 0.158$ & $3.727 \pm 0.109$ \\
\hline \multirow{2}{*}{ Conjugate at $4^{\circ} \mathrm{C}$ for $16 \mathrm{~h}$} & Undiluted & $3.643 \pm 0.087$ & $3.549 \pm 0.164$ \\
\hline & $1: 5000$ & $3.708 \pm 0.093$ & $3.732 \pm 0.069$ \\
\hline \multirow[t]{2}{*}{$\mathrm{HRP}$ at $37^{\circ} \mathrm{C}$ for $2 \mathrm{~h}$} & Undiluted $^{\mathrm{c}}$ & $3.821 \pm 0.064$ & $3.871 \pm 0.049$ \\
\hline & $1: 5000$ & $3.256 \pm 0.080$ & $3.545 \pm 0.067$ \\
\hline \multirow[t]{2}{*}{ HRP at $4^{\circ} \mathrm{C}$ for $16 \mathrm{~h}$} & Undiluted & $3.789 \pm 0.074$ & $3.801 \pm 0.028$ \\
\hline & $1: 5000$ & $3.437 \pm 0.077$ & $3.681 \pm 0.075$ \\
\hline \multicolumn{4}{|c|}{ 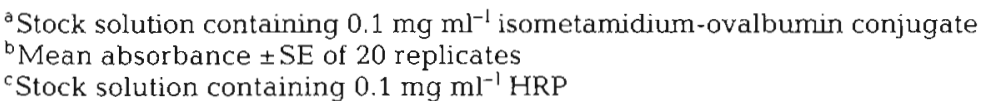 } \\
\hline
\end{tabular}


Table 2. Optical density values (at $405 \mathrm{~nm}$ ) using a horseradish peroxidase (HRP) saturation technique to determine the coating of anti-isometamidium antibodies to polystyrene microtitre plates

\begin{tabular}{|c|c|c|c|}
\hline \multirow[t]{2}{*}{ Antigen } & \multirow[t]{2}{*}{ Dilution } & \multicolumn{2}{|c|}{$\begin{array}{c}\text { pH of carbonate-bicarbonate } \\
\text { coating buffer }\end{array}$} \\
\hline & & 7.0 & 9.6 \\
\hline \multirow[t]{2}{*}{ Antibody at $37^{\circ} \mathrm{C}$ for $2 \mathrm{~h}$} & Undiluted $^{\mathrm{a}}$ & $2.210 \pm 0.072^{b}$ & $3.717 \pm 0.067$ \\
\hline & $1: 5000$ & $3.717 \pm 0.067$ & $3.878 \pm 0.128$ \\
\hline \multirow[t]{2}{*}{ Antibody at $4^{\circ} \mathrm{C}$ for $16 \mathrm{~h}$} & Undiluted & $2.838 \pm 0.095$ & $3.043 \pm 0.092$ \\
\hline & $1: 5000$ & $3.795 \pm 0.031$ & $3.831 \pm 0.076$ \\
\hline \multirow[t]{2}{*}{$\mathrm{HRP}$ at $37^{\circ} \mathrm{C}$ for $2 \mathrm{~h}$} & Undiluted $^{c}$ & $3.897 \pm 0.098$ & $3.866 \pm 0.019$ \\
\hline & $1: 5000$ & $3.456 \pm 0.059$ & $3.585 \pm 0.034$ \\
\hline \multirow[t]{2}{*}{$\mathrm{HRP}$ at $4^{\circ} \mathrm{C}$ for $16 \mathrm{~h}$} & Undiluted & $3.806 \pm 0.071$ & $3.878 \pm 0.065$ \\
\hline & $1: 5000$ & $3.369 \pm 0.073$ & $3.594 \pm 0.086$ \\
\hline \multicolumn{4}{|c|}{ 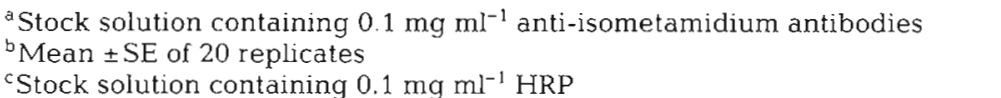 } \\
\hline
\end{tabular}

the anti-isometamidium antibody had a greater affinity for polystyrene than HRP at $37^{\circ} \mathrm{C}$ and $\mathrm{pH}$ 7.0. Less binding of antibodies occurred at lower temperatures and in alkaline $\mathrm{pH}$ (Table 2).

The same experimental procedure was used to determine the optimum solid phase antigen concentrations of anti-isometamidium antibodies. A 1:10 dilution of antibodies at $\mathrm{pH} 7.3$ was optimum for plate coating and less binding occurred at more alkaline $\mathrm{pH}$ (Table 3). A significant difference was not detected between the mean absorbance of $1: 10,1: 100(p=0.8564)$ or $1: 1000$ $(p=0.5842)$ dilutions of antibodies. Differences were detected between 1:3000 $(p=0.0487)$ and $1: 5000(p=$ 0.0312 ) dilutions. To conserve anti-isometamidium antibodies, a 1:1000 dilution was used in the antigen capture ELISA

The ELISA detected isometamidium in plasma to a concentration of $0.6 \mathrm{ng} \mathrm{m}^{-1}$. The optical density values decreased with decreasing concentrations of isometamidium and peaked at a concentration of $1.2 \mathrm{mg} \mathrm{ml}^{-1}$. There was a sharp decline in the optical density values when there was more than $1.2 \mathrm{mg} \mathrm{ml}^{-1}$ of isometamidium with equilibrium reached at a concentration of $1.2 \mathrm{mg}$ $\mathrm{ml}^{-1}$ (Fig. 1). There were no significant differences between isometamidumspiked plasma and naïve plasma ( $\mathrm{p}=$ 0.0843 ) at less than $0.6 \mathrm{ng} \mathrm{ml}^{-1}$ of drug. A significant difference was not detected between the optical density values of isometamidium-spiked plasma and isometamidium-spiked saline at concentrations between $5.0 \mathrm{mg} \mathrm{m}^{-1}$ and $0.05 \mathrm{mg} \mathrm{ml}^{-1}$ (Fig. 2). At concentrations less than $0.05 \mathrm{mg} \mathrm{ml}^{-1}$, isometamidium diluted with saline could not be detected using the ELISA.

\section{DISCUSSION}

The nature of the binding of antigen to polystyrene plates is not well understood. Antigen binding depends on the nature of the antigen, antigen concentration, temperature, time of incubation and $\mathrm{pH}$ of the coating buffer (Venkatesan \& Wakelin 1993). In the present study the greatest binding affinity of both antigens for polystyrene occurred at neutral $\mathrm{pH}$, high temperatures and short incubation times. Several factors may account for these differences. Commonly, if coating is carried out at $4{ }^{\circ} \mathrm{C}$, the cooler outer wells in the plate may bind less antigen than the inner wells and produce an 'edge effect' which will affect subsequent stages of the ELISA technique. The longer incubation time (16 h) may lead to overcrowding and concealment of epitopes and consequently antibody binding is diminished.

The usual method to determine the optimal antigen concentration is to use immune serum and proceed with the ELISA. It is generally assumed that the opti-

Table 3. Optimum anti-isometamidium antigen concentration for coating of polystyrene surface sites $\left(37^{\circ} \mathrm{C}\right)$ using a horseradish peroxidase (HRP) saturation technique

\begin{tabular}{|c|c|c|c|c|c|c|c|}
\hline \multirow[t]{2}{*}{ Dilution $^{a}$} & \multicolumn{7}{|c|}{$\mathrm{pH}$ of carbonate-bicarbonate coating buffer } \\
\hline & 7.0 & 7.3 & 7.4 & 8.0 & 8.5 & 9.0 & 9.6 \\
\hline No. Dilution & $2.157 \pm 0.049^{h}$ & $2.117 \pm 0.060$ & $2.646 \pm 0.033$ & $3.272 \pm 0.079$ & $3.601 \pm 0.064$ & $3.617 \pm 0.042$ & $3.649 \pm 0.089$ \\
\hline $1: 10$ & $2.272 \pm 0.049$ & $2.216 \pm 0.017$ & $2.847 \pm 0.071$ & $3.338 \pm 0.024$ & $3.648 \pm 0.013$ & $3.674 \pm 0.034$ & $3.771 \pm 0.028$ \\
\hline $1: 100$ & $2.307 \pm 0.071$ & $2.396 \pm 0.029$ & $2.930 \pm 0.067$ & $3.374 \pm 0.082$ & $3.676 \pm 0.029$ & $3.771 \pm 0.061$ & $3.786 \pm 0.081$ \\
\hline $1: 1000$ & $2.449 \pm 0.057$ & $2.616 \pm 0.016$ & $3.449 \pm 0.017$ & $3.586 \pm 0.107$ & $3.757 \pm 0.093$ & $3.786 \pm 0.082$ & $3.721 \pm 0053$ \\
\hline $1: 3000$ & $3.533 \pm 0.030$ & $3.349 \pm 0.070$ & $3.642 \pm 0.042$ & $3.690 \pm 0.057$ & $3.813 \pm 0.048$ & $3.811 \pm 0.078$ & $3.819 \pm 0.039$ \\
\hline $1: 5000$ & $3.764 \pm 0.053$ & $3.648 \pm 0.049$ & $3.947 \pm 0.034$ & $3806 \pm 0.044$ & $3.846 \pm 0.055$ & $3.985 \pm 0.071$ & $3.839 \pm 0.067$ \\
\hline $\mathrm{HRP}^{c}$ & $3.817 \pm 0.045$ & $3.878 \pm 0.037$ & $3.804 \pm 0.012$ & $3.836 \pm 0.075$ & $3.820 \pm 0.064$ & $3.884 \pm 0.047$ & $3.842 \pm 0.021$ \\
\hline \multicolumn{8}{|c|}{$\begin{array}{l}\text { "Stock solution containing } 0.1 \mathrm{mg} \mathrm{ml}^{-1} \text { protein } \\
\text { "Mean absorbence at } 405 \mathrm{~nm} \pm \mathrm{SE} \text { of } 20 \text { replicates } \\
\text { "Stock solution containing } 0.1 \mathrm{mg} \mathrm{ml}{ }^{-1} \mathrm{HRP}\end{array}$} \\
\hline
\end{tabular}




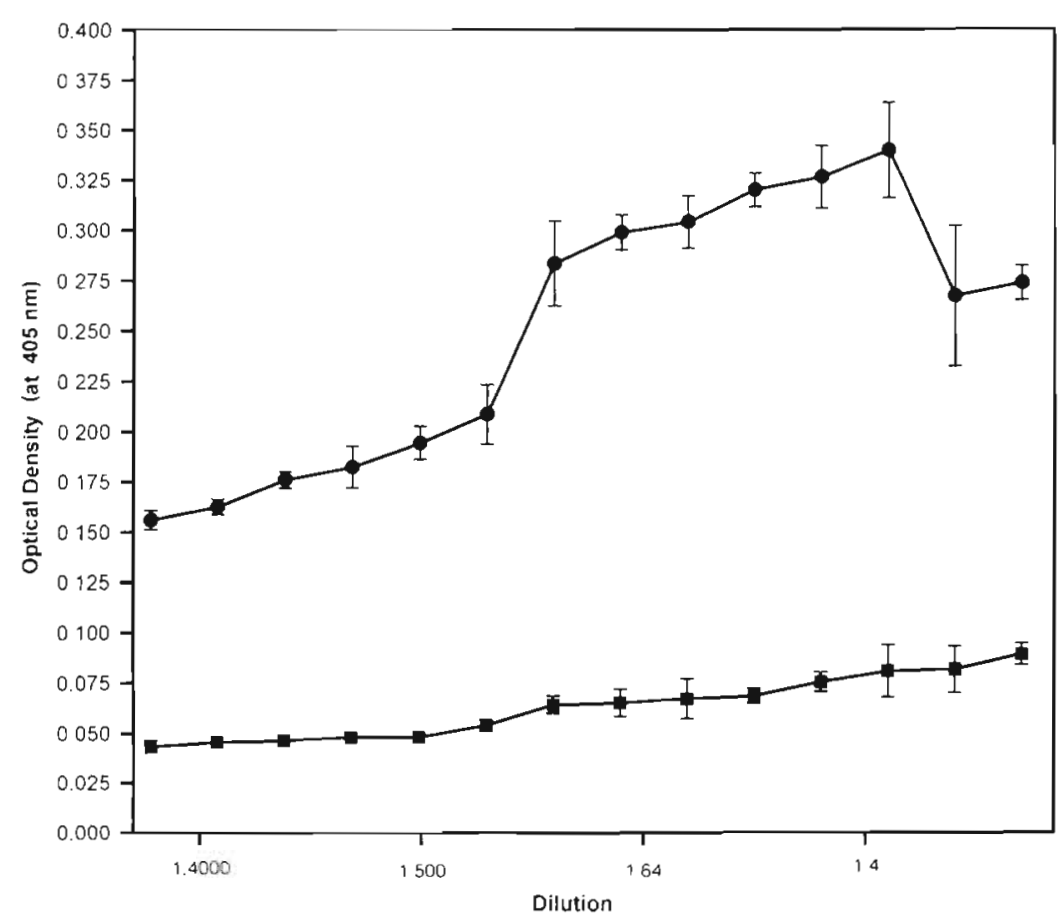

Fig. 1. Standard curve for detection of isometamidium in rainbow trout plasma. (•) Plasma from rainbow trout with isometamidium serially diluted with PBS; (-) plasma from rainbow trout serially diluted with PBS. The concentrations of isometamidium ( $\mathrm{mg} \mathrm{ml}^{-1}$ ) which correspond to the dilution factor indicated by the $x$-axis are as follows: $1: 4000=0.0012 ; 1: 500=0.0098 ; 1: 64=0.078 ; 1: 4=1.25$ and immunoelectrophoresis confirmed isometamidium-specific antibodies in fish plasma. The affinity of the conjugate for plates may be improved by increasing the concentration of protein in the original conjugate, and this decreases the amount of antigen lost during washing.

Two other assays have been developed for the detection of isometamidium in the sera of cattle (Whitelaw et al. 1991, Eisler et al. 1993). Both of these assays were presumed to be more sensitive and required less sample, however they did not have a blocking step in the ELISA. Perhaps their higher 'sensitivity' may be due to some nonspecific binding because they did not have a block step. There are 2 approaches to minimize nonspecific binding; one is to wash thoroughly and the other is to block vacant sites with another protein. The best approach is to block sites as washing may remove specific as well as nonspecific antigens (Venkatesan \& Wakelin 1993). Our results of the peroxidase saturation technique revealed mum antigen concentration for coating ELISA plates is the one needed to obtain the maximum optical density reading with a control antibody sample (chequerboard titration). However, this method does not take into account the influence of avidity (Muñoz et al. 1986). For this reason, a peroxidase saturation technique for the determination of coating antigen concentration necessary to saturate polystyrene plates was used in the current study. With this technique, peroxidase is incubated on plates coated with antigen; vacant sites are filled by the enzyme and its presence is detected by the addition of substrate. Minimal peroxidase activity corresponds to maximal antigen coating (Muñoz et al. 1986). Anti-isometamidium antibodies had higher affinity for polystyrene plates as compared to the conjugate. Low binding might be due to small quantities of ovalbumin in the conjugate and thus not enough protein was present to bind to surface sites. The results demonstrated that the integrity of isometamidium was not affected by the diazotization reaction

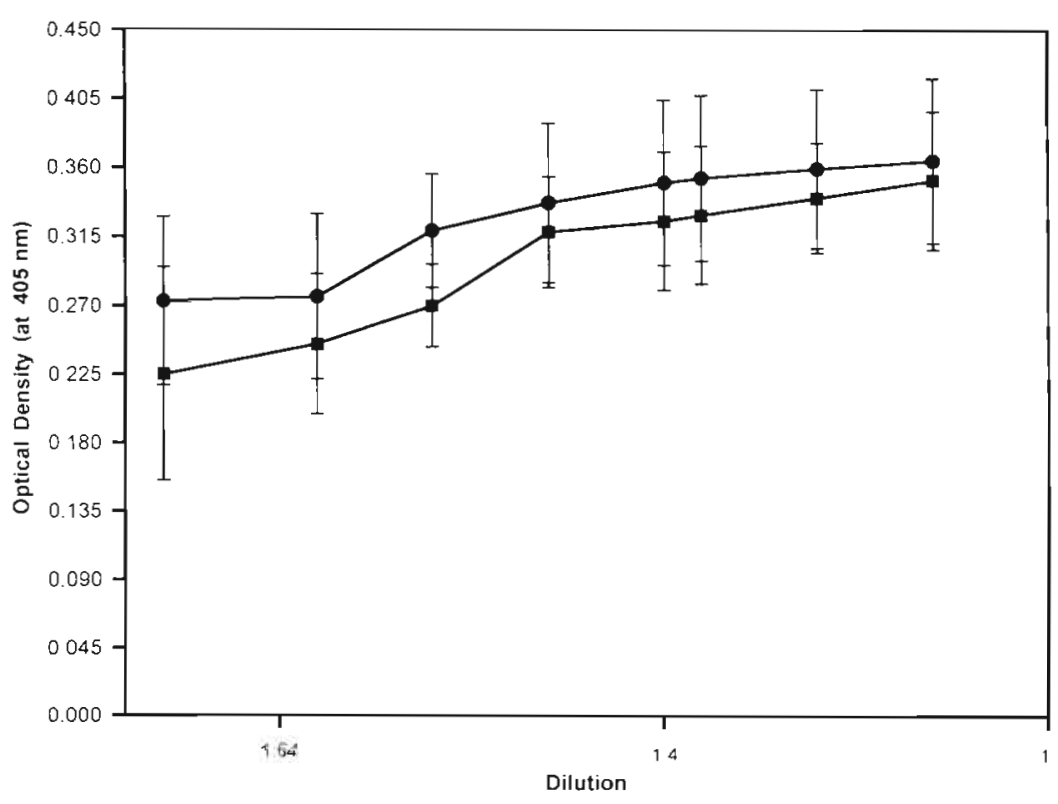

Fig. 2. Sensitivity of ELISA for detection of isometamidium in rainbow trout plasma. The concentrations of isometamidium $\left(\mathrm{mg} \mathrm{ml}^{-1}\right)$ which correspond to the dilution factor indicated by the $x$-axis are as follows: $1: 64=0.078 ; 1: 4=1.25 ; 1=5.0$ 
vacant sites would be available for other proteins (albumin or globulin) in the test sample, particularly over long incubation times (e.g. overnight incubations). Thus, the optical density value of the test sample might have included the anti-immunoglobulin enzyme conjugate binding nonspecifically to vacant sites in the plastic wells.

Philips et al. (1967) showed that isometamidium is strongly bound by polyanionic macromolecules such as nucleic acids, mucopolysaccharides and serum albumin. The binding of the drug to albumin may explain the sensitivity of the ELISA when isometamidium was diluted in plasma, but not in saline. The present ELISA detected $0.0006 \mathrm{mg} \mathrm{ml}^{-1}$ when isometamidium was diluted in plasma but only detected $0.05 \mathrm{mg} \mathrm{ml}^{-1}$ when diluted in saline. The drug is a low molecular weight compound ( $\mathrm{MW}=531.5$ ) and a protein conjugate is required to stimulate trout to produce antibodies against it. It is likely that the drug is detectable at low concentrations in plasma because the albumin binds to it as a protein conjugate, thus producing a larger molecule for the anti-isometamidium antibody. When diluted in saline the drug is only detectable at a higher concentration because of its small size.

Chemotherapy against salmonid cryptobiosis is often necessary, as about 50 to $60 \%$ of Oncorhynchus tshawytscha broodstock in a Washington State hatchery die from the disease annually (L. Peck pers. comm. 1994), and there was an outbreak of the disease which occurred in 1997 in pre-harvest salmon in sea cages off Vancouver Island, British Columbia (S. Saksida pers. comm.). Also, the drug may be effective against other fish diseases and the ELISA technique would be useful to monitor isometamidium in the blood of treated fish.
Acknowledgements. This study was supported by grants from the National Science and Engineering Research Council (NSERC) of Canada to P.T.K.W. The isometamidium was a donation from Dr Andrew Peregnne (Department of Pathobiology, Ontario Veterinary College).

\section{LITERATURE CITED}

Bradford MM (1976) A rapid and sensitive method for the quantitation of microgram quantities of protein utilizing the principle of protein-dye binding. Anal Biochem 72 : $248-254$

Eisler MC, Gault EA, Smith HV, Peregrine AS, Holmes PH (1993) Evaluation and improvement of an enzyme-linked immunosorbent assay for the detection of isometamidium in bovine serum. Ther Drug Monit 15:236-242

Muñoz C, Nieto A, Gayá A, Martínez J, Vives J (1986) New experimental criteria for optimization of solid-phase antigen concentration and stability in ELISA. J Immunol Methods $94: 137-144$

Oudin J (1980) Immunochemical analysis of antigen-antibody precipitation in gels. Meth Enzymology 70:166-198

Philips FS, Sternberg S, Cronin A, Sodergren SA, Vidal PM (1967) Physiologic disposition and intracellular localization of isometamidium. Cancer Res 27:333-349

Smith SA (1992) Affinity purification of serum immunoglobulin from fish. In: Stolen JS, Fletcher TC, Anderson DP, Kaattari SL, Rowley AF (eds) Techniques in fish immunology. SOS Publications, Fair Haven, NJ, p $125-130$

Venkatesan P, Wakelin D (1993) ELISA's for parasitologists: or lies, damned lies and ELISA's. Parasitol Today 9:228-232

Whitelaw DD, Gault EA, Holmes PH, Sutherland IA, Rowell FJ, Phillips A, Urquhart GM (1991) Development of an enzyme-linked immunosorbent assay for the detection and measurement of the trypanocidal drug isometamdium chloride in cattle. Res Vet Sci 50:185-189

Woo PTK, Poynton SL (1995) Diplomonadida, Kinetoplastida and Amoebida (Phylum Sarcomastigophora). In: Woo PTK (ed) Fish diseases and disorders, Vol 1. Protozoan and metazoan infections. CAB International, Oxon, p 27-96

Submitted: March 5, 1999; Accepted: September 23, 1999 Proofs received from author(s): January 18, 2000 